\title{
VULNERABILITY TO FOREIGN MACROECONOMIC SHOCKS \\ - AN EMPIRICAL STUDY IN CROSS-INDUSTRY PERSPECTIVE. \\ EXAMPLE OF 2008-2009 GLOBAL CRISIS IN EUROPE*
}

\author{
Agnieszka Domańska, Ph.D. \\ Warsaw School of Economics \\ Institute for International Studi \\ Al. Niepodległości 162, 02-554 Warszawa, Poland \\ e-mail:az.domanska@gmail.com \\ Dobromił Serwa, Ph.D. \\ Warsaw School of Economics \\ Institute of Econometric \\ Al. Niepodległości 162, 02-554 Warszawa, Poland \\ e-mail:dserwa@sgh.waw.pl
}

Received 22 August 2013, Accepted 12 November 2013

\begin{abstract}
The paper analyses the factors explaining the vulnerability of the European countries' industries to foreign trade and production downturn in the years 2008-2009 and attempts to identify branches and industries (or their features significant in this context) that most greatly contributed to the last crisis transmission in Europe, mainly through the slump in their trade. Among those factors we took into particular consideration: the level of specialization versus diversification of the export basket and production, trade openness in the cross-country and cross-industry perspective, the intra-industry/inter-industry structure of trade and the financial openness.
\end{abstract}

Keywords: global crisis, exposure to foreign shocks, globalization.

JEL classification: F14, F15, F41.

* The reasearch presented in the herewith article were executed under the resaerch project „International transmission of shocks and the vulnerability of the European economies to the global crisis 2007-2009" financed by the National Science Centre (application no N N112 377940). 


\section{Introduction}

Nowadays, when globalization of the world economy is gathering pace dynamically, the issues of international transmission of economic shocks and mutual economic relations among various countries and markets often located at far distances from each other constitutes the area of interest for one of the major open-economy macroeconomics research trend. One of the key facets of this issue are the channels transmitting business cycle impulses both during global or regional downturns (impacts of negative shocks) and in stable economic conditions. The authors covering the problem in their papers generally agree that, in addition to international financial capital flows, foreign trade is the other major transmission channel of economic shocks between countries.

The vital role that foreign trade plays in transmitting economic shocks internationally was confirmed during the last global crisis in 2008-2009: a substantial drop in the global trade affected aggregate output in most countries in the world ${ }^{1}$. The depth and geographical range of the downturn in international trade had been the greatest for over 70 years and frequent comparisons to the Great Depression in the 1930s indicate that the recent crisis had even more serious consequences (the fall in the world trade that occurred within 15 months after the US' mortgage market crash was almost twice as big as the one that occurred within the same period after the beginning of the pre-war crisis).

Reports and numerous analyses concerning the crisis effects (incl. World Economic Outlook, World Financial Stability Report, World Trade Organization reports, other World Bank, IMF, OECD reports and analyses, etc.) indicate though that the recession consequences in their broad sense, including decline in international trade, influenced particular regions and countries of the world to a different extent. The scale of trade downturn also differed in regard to particular industries. Substantial differences in the impacts of the crisis in cross-country and cross-industry comparisons poses interesting problems for the researcher. Firstly of all: what are then the reasons for different levels of national economies' sensitivity (vulnerability, or as defined in literature - "exposure") to business cycle influences from abroad?2. Another problem issue is also to discover which factors determine the vulnerability of the diverse industries to the negative foreign (global) shocks. This latter problem is tackled in the herewith study and exemplified with the impact of the 2008-2009 crisis on the production and trade of the different industries in Europe.

The hereby article aims at analysing the factors explaining particular industries' vulnerability to foreign trade and production downturn in the years 2008-2009 and attempts to 
identify branches and industries (or their features significant in this context) that most greatly contributed to the last crisis transmission in the European countries through the slump in their trade. The paper consists of two parts: a theoretical and an empirical one. The first part covers a topic-relevant literature review and presents the selected views elaborated in the literature, concerning particularly the trade openness, product diversification of trade, an importance of inter-industry versus intra-industry structure of trade etc. In the second. i.e. an empirical part, the authors carried out the regression analysis using indicators and data (as factors) selected according to the pattern of other authors' studies review. We used the approach similar to other authors when running several specifications of the regression model.

The factors of the present study include in particular: the economy and export branch structure, the level of specialization versus diversification of the export basket and production, trade openness at the level of countries and branches, the intra-industry/inter-industry structure of trade as well as the openness to international financial flows. The vulnerability of particular industries to the crisis itself was shown through estimating the so called "crisis costs" born by industries. Those costs were calculated by means of an appropriate quantitative method (economic literature).

To meet the above research objective, it was necessary to gather a considerable amount of statistical data. The input data for the estimated econometric models come from the largest base (and the most detailed one as regards the level of data aggregation) that collects information on production and exports, i.e. INDSTAT 2-digit, INDSTAT 4-digit and Demand-Supply Database (IDSB) of UNCTAD, as well as data from other resources, mainly IMF World Economic Outlook and IMF world financial databases. The earliest data come from 1990.

To the authors' knowledge, the title issues have not been presented so far in the Polish economic literature in a complex way. Neither has an empirical analysis on the subject been done by the Polish authors although it has been broadly covered by the world literature, including numerous empirical studies. Thus the present paper is innovative in the Polish economic literature. It is worth adding that despite referring to the past crisis and the sample of several European countries, the issues hereof are significant when addressing generally the weighty question: which macroeconomic factors connected to international trade determine not only the economies' sensitivity to foreign influence, but also their capability to meet the challenges of global recessions and strengthen their competitiveness afterwards. 


\section{The role of foreign trade in the international transmission of economic impulses} - a literature review and discussion

\subsection{Trade and macroeconomic shocks transmission}

To put it simply the involvement in foreign trade (particularly as regards exports) by itself exposes domestic entities to external shocks: a positive impulse for the economy results from a positive demand shock in partner countries, whereas "importing" a slump is related to income decrease and the limitation of foreign market demands. Thus the channel of transmitting economic impulses between countries revolves around foreign demand fluctuations, influencing domestic production at the level of industries. The changes in foreign demand have multiplying effects on domestic aggregate economic results, if those changes are significant and affect numerous production (and service) branches. Thus, in the real economy business cycle impulses and shocks are transmitted by means of international interdependencies, companies' collaboration and trade linkages, so it is at the level of products and branches ${ }^{3}$.

However, this mechanism will differ depending on an economic sector, partner markets diversification, the presence of long-term cooperation linkages, substitutes for traded goods affected by any demand shock from abroad, the basket structure of trade, the "type" of the trade (i.e. exclusive imports, fill-in imports, specialized exports) ${ }^{4}$. Also, the values of income elasticities of imports and exports vary (the former being higher than 1, and the latter ranging from 0 to 1, which means that during a boom imports increase faster than GDP; and during a slump they decline faster than income; exports do not react so strongly). A more detailed analysis of this issue is included in the author's other studies ${ }^{5}$.

The role of foreign trade as a channel of financial crisis transmission has been covered by numerous empirical studies. Some of them were conducted within the framework of non-crisiscontingent theories or interdependence theories which assume that international business cycle transmission mechanisms are similar when the economy is stable and when it suffers downturns (even the global ones). Some other research focus on trade and competitive devaluation roles, which refers among others to transmitting financial and currency crises through the trade channel.

One of the first studies on the significance of foreign trade for transmitting economic (financial) crises was that by B. Eichengreen and A.K. Rose (1999). They examined the (time) correlation between the crisis probability (the data covered 20 highly developed economies in 1959-1993) and a speculative attack in those countries' trade partners' economies. The correlations were weighed with bilateral trade and a set of macroeconomic variables. The analysis 
proved the correlations between crisis contagion and mutual trade (research in country pairs) 6 R. Glick and A.K. Rose (1999) ${ }^{7}$ conducted a study referring to 5 main crises that appeared in the world between 1971 and 1997. The authors utilized several measures concerning trade linkages of different types (they took into account not only bilateral trade, but also a competitive relation in the third country's markets, their combination, the exports to common markets weighed with the market size etc.), and they generally concluded that countries' exposure to mutual currency crisis contagion is strongly dependent on the strength of the trade linkages between them ${ }^{8}$.

One of the recent studies is by K. Forbes (2000) who applied statistics at a company level (information from over 10,000 companies from all over the world that operated in the countries affected by the Asian and Russian crises). The author tried to find out which industries incurred the highest losses due to the aforementioned regional downturns and how the international linkages (collaboration and international trade) between companies functioned as a channel of crisis transmission. The results obtained by K. Forbes revealed that the entities selling their products in the infected markets or those competing with enterprises from the countries suffering crises gained considerably lower profits during economic slumps.

In her subsequent study, K. Forbes indicated the existence of three channels, through which trade linkages transmit economic crises ${ }^{9}$. They are: a competitiveness effect (connected with changes in relative prices), an income effect (a crisis influences income and the demand for imports) and a cheap-import effect (a crisis reduces import prices for a trading partner and acts as a positive supply effect). The author concluded that the combined influence of the three channels explains about one fourth of the variation in capital market returns during the crises analysed, and she additionally found out that other international linkages, such as financial flows, are also important to transmitting downturns between countries ${ }^{10}$.

Other studies include the research of A. Burstein, Ch. Kurz and L. Tesar (2008) who analysed the relation between production sharing (data on the trade between US companies and their affiliates in Mexico as well as between the USA and Mexican maquiladoras) and business cycles.

A. Levchenko et al (2009) analysed crisis transmission by international trade with reference to 2008-2009 crisis. The authors consider international trade collapse as the most striking feature of the last global economic slump. Analysing monthly and quarterly data on the US exports and imports during the crisis, they conclude that the scale of trade decrease in comparison to GDP decline was considerably larger in the examined period than in case of previous recessions in the world economy. According to the authors, the detailed data (6-digit level in NAICS) indicates that the import gap is as much as $50 \%$ higher than it would result from estimating the simple relation 
of export scale to foreign demand (this concerns especially industries producing intermediate goods). B. Eichengreen and K.H. O’Rourke compared two global economic slumps: the Great Depression in the 1920s and the present situation in the context of international trade collapse ${ }^{11}$. Basing on the data about the trade and industrial production decrease, the authors proved that both recessions had been transmitted between countries by means of trade and capital flows, as well as by changes in product prices on the world markets. A detailed analysis of reasons for the spectacular trade downturn in 2008-2009 is the subject of numerous other studies ${ }^{12}$.

\subsection{Foreign trade features and structure as determinants of vulnerability to foreign macroeconomic influences: openness, diversification and intra-industry trade}

International trade openness is the starting point for presenting the discussion on trade features as determinants of the countries' exposure to external business cycle impulses ${ }^{13}$. The level of an economy's openness, both the trade and financial one ${ }^{14}$, constitutes the key determinant (a negative or a positive one) of external impulse impact on the economy's performance. Openness plays a multifaceted role which is connected not only to the simple dependence of particular producers and whole industries on the volatile demand in foreign markets. Tight international linkages additionally loosen a particular industry's relations to the rest of the national economy and they change the features of the common course of highly international branches or industries' output fluctuations and a country's business cycle ${ }^{15}$. Foreign trade also changes the primary structure of an economy, thus causing changes at the level of specialization, production character and product diversification in industry branches, etc. Exposing the economy to external effects, the openness may also function as a buffer accommodating the external shock impact ${ }^{16}$. Some studies showed the trade openness influence on output and income ${ }^{17}$. At the level of industries, the problem was examined by such authors as D.M. Newbery and J.E. Stiglitz (1994) who suggested that industry in an open economy is more vulnerable to global demand and supply shocks. D. Dollar 1992, D. Ben-David (1993) or W. Easterly and S. Rebelo (1993) proved an adverse effect of the trade openness on the level of per capita income. On the other hand, D. Rodrik and F. Rodriguez (2000) stated that the influence of the openness on the level of economic development is insignificant ${ }^{18}$.

Many dissertations have focused on how an economy's external openness through trade relations is tied to aggregate product fluctuations. The majority of empirical studies therein proved that the relation between those aggregates is positive ${ }^{19}$, i.e. the exposure to the rest of the world economy enhances fluctuations of a domestic aggregate product, income etc. 
Apart from an economy's trade openness other significant factors describing the vulnerability to external shocks come from the character (i.e. the structure) of the trade. Three factors can be taken into consideration (as mentioned in A. Domańska 2011 (b), A. Domańska 2012): product composition of the export basket, trade diversification versus specialisation, intra- vs. inter-industry trade.

The discussion on the relation between the trade basket structure and the economic growth covers two problems:

- is the composition itself important, e.g. the majority of natural resources, agricultural products or other primary branches' products versus highly processed products in a particular country's exports?, or

- is it more significant for a country to possess a more or less product-diversified export basket?

The research on those issues based on quantitative methods was booming in the 1980s and later on $^{20}$. Studies based on empirical data resulted in "stylized facts" accepted in this area ${ }^{21}$.

The first of them is the claim that the less diversified (focused on precise needs of the world consumers) export structure contributes to increased business cycle fluctuations in a particular economy and intensifies its exposure to external shocks: in this situation GDP is affected by the world demand through trade which is poorly diversified as regards industries. Domestic producers' exposure to international market price volatility is responsible for this situation. To put it simply, in case of exports based on a narrow basket of goods, the influence is more instable due to the dependence on inelastic and volatile global demand than it would be if the countries' product and service offer for international markets was more diversified. Following this, it is thought that excessive concentration, i.e. the export income dependence on a small number of goods sold on foreign markets, leads to larger export price volatility, which in turn causes greater macroeconomic fluctuations; thus the above mentioned factor may lower GDP (especially when the world demand weakens). As early as in 1958, M. Michealy ${ }^{22}$ stated in his studies that countries with lower GDP per capita are usually noted for greater export concentration around certain product groups; it is because shocks affecting individual industries or product types translate into the condition of exports and the whole economy. J. Love (1986) proved a positive dependency between product concentration and export fluctuations, which, according to him, contributes to income fluctuations indirectly. The author enriched his conclusions with the observation that product diversification may reduce export income instability if changes in prices of new products sent to foreign markets are not strongly correlated with prices of domestic products traded internationally ${ }^{23}$. 
On the other hand, narrower specialization enables better utilization of economies of scale, which increases productivity of an economy.

Moreover, theoretical justification for specialization can be found in rudimental concepts, such as Ricardo's theory, the agglomeration effects (decreasing transport costs combined with economies of scale lead to the decline of the number of goods being produced), or the business concentration externalities, thanks to which clustering of various industry branches in one place becomes profitable.

An overview of studies and concepts presented in the literature made us conclude that the issue is questionable. In other words there is no common and undeniable consent on whether the higher specialization or higher concentration provide for more vulnerability to external economic impulses (at the same time more or less immune from the negative shocks). This means that the problem should be detected each time in relation to the particular time and the group of countries having their specific characteristic (i.e. using different sets of data) which has made the authors of the hereby article to take up the issue by studying the case of the European countries in the years 2008-2009 (the strength of the influence of the global crisis).

There is a number of empirical research devoted to the question whether the higher specialization or higher concentration of the export/production provide for more vulnerability to external economic impulses ${ }^{24}$.

The majority of results of the empirical research shows that the more diversified the export basket and more diversified the production structure of the country, the more prone the domestic economy to international transmission of shocks. Although some results do not confirm this or show only negligible relation between the economy and trade diversification level and the effects of foreign countries on domestic economy, the preposition of the positive correlation between the high concentration of production and the export basket and the vulnerability to foreign influences has become an stylised fact accepted by most researchers.

Another factor that may affect the role of trade in transmitting impulses (including economic crises) is its inter-industry versus intra-industry character.

In case of inter-industry trade, according to Heckscher-Ohlin trade theory, the reduction of trade barriers between countries leads to an international division of labour, which means particular countries' specializing in production. This implies inter-industry trade model in which the shocks that are characteristic of certain industries (for example price shocks) function within a single country and they do not tend to spread to (infect) industries in other countries. As a result of these asymmetric shocks, mutual partners' exposure to external influence is lower (additionally, the extent of business cycle synchronization of particular economies 
becomes weaker). This scenario was mentioned, e.g. by Krugman (1993) in "Lessons of Massachusetts" 25 , where he emphasized that trade integration may lead to specialization and thus increase asymmetric shock probability and make fluctuations not more, but quite opposite - less correlated. In this case the mutual international influences are not so strong which may suggest that the countries with more inter-industry trade are not so vulnerable to the negative economic shocks from abroad (i.e. those transmitted internationally) ${ }^{26}$.

The other approach assumes that a fast growth of international trade contributes to its shift towards intra-industry structure. It is due to the fact that particular production process stages are divided between subcontractors or subsuppliers in various countries; thus international trade becomes vertical. In this situation, the sector-specific shocks in one country spread by means of close corporate linkages to cooperative industries in other countries, in the areas of free trade. The same effect is observed in case of horizontal intra-industry trade (countries trade and compete with the same products). To sum up, in the literature an opinion exists that the intraindustry trade contributes generally to higher vulnerability to the international economic shocks (such as a global crisis shock) than the inter-industry trade. Moreover, the intra-industry trade is thought to currently prevail in the world ${ }^{27}$. This preposition is considered to be the stylised fact accepted by the majority of the researchers ${ }^{28}$.

\section{The structure and features of the European countries' trade as factors of 2008-2009 crisis vulnerability. An empirical study}

Basing on a literature review, the applied research methods and data that other authors utilized in their studies on the issues discussed in this paper, the authors hereof conducted the following analysis by means of quantitative methods. The analysis is aimed at detecting the factors of vulnerability of particular industries in the European economies (cross-country and cross-industry data) to the influence of the shock of the global crisis. To do this, several specifications of the regression models were run. The authors have used a number of different variables as factors potentially explaining the exposure of branches to collapse resulting from the international transmission of the global economic slowdown. The explained variable, i.e. the direct expression of the industries' vulnerability to the global crisis shock is the so called "crisis cost" born by each branch due to the 2008-2009 slump. The methodology will be presented in more details later on.

To conduct the analysis, an extensive database was collected coming from international data sources. There was also the need to unify the data coming from different statistics with different 
levels of aggregation (the authors aggregated the information from the four-digit classification into the two-digit classification in order to obtain one uniformed database). All the statistical information originate from the extended UNCTAD bases, INDSTAT 2-digit, INDSTAT 4-digit and IDSB, i.e., Demand - Supply Database. The data concern:

- production, general exports (i.e., to all countries in the world), general imports for 37 industrial branches in the European countries. Working on the above mentioned data involved aggregating the information on production from 241 product groups into 37 industrial branches for all the analysed European countries (the ones for which the data was available),

- aggregate production value in all the analysed countries in 1990-2009,

- number of other data from the international IMF and OECD statistical databases,

- indicators (computed by the authors) of: openness, production and export concentration/ diversification, as well as the intra-industry trade.

As mentioned above, the study presented in this article defines particular industries' vulnerability to crisis through the so called crisis costs broken down by industries in the European countries. As explanatory variables the authors used an extensive number of macroeconomic categories denoting the character of the analysed countries' production and export (i.e. the level of its diversification, intra- versus inter-industry trade) as well as the general macroeconomic characteristics showing the country-specific factors of the European countries vulnerability to the 2008-2009 crisis' costs.

\subsection{The crisis costs in the European industry branches}

This study method of comparing the 2008-2009 crisis' costs borne by the industry branches in the European countries is patterned on similar research carried out by another authors ${ }^{29}$. Those costs reflect the vulnerability (exposure) to the spread of the global crisis in Europe in the crossindustry perspective. The crisis costs are denoted by the production gap, i.e. the decrease in the production of an industry in relation to its theoretical (potential) output resulting from a 10-year trend (more precisely - the deviation of the output from this trend). Then the authors compare those crisis costs in the cross-industry perspective, concluding which industries suffered the greatest fall due to the global economic crisis. Concurrently the authors calculate the crisis costs in all the European countries (they have decided not to show the results due to the limited expected volume of the article $)^{30}$.

To calculate the crisis costs in each (of the 27 analysed) industries $i$, the real output $Y_{i t}$ in this industry in the period $t$ of the crisis is compared to the potential production level $Y_{i t}^{*}$ 
computed on the basis of a long-term production trend before the crisis. Then the industry's crisis costs are measured (as a percentage) in the following way:

$$
\Delta y_{i t}=\frac{Y_{i t}-Y_{i t}^{*}}{Y_{i t}^{*}} \cdot 100 \% \quad \text { for } t=2008,2009
$$

A theoretical long-term production level is calculated by means of the following equation:

$$
Y_{i t}^{*}=\left\{\begin{array}{cc}
Y_{i t} & \text { for } t<2008 \\
Y_{i t-1}^{*} \cdot\left(\frac{Y_{i, 2007}}{Y_{i, 1998}}\right)^{\frac{1}{10}} & \text { for } t \geq 2008
\end{array}\right.
$$

The production decrease accumulated within the whole crisis period is calculated by adding up the decrease from subsequent periods of the crisis. For example the accumulated decrease of production in the economy's branch $i$ in 2008 and 2009 amounts to:

$$
S_{i}=\sum_{t=2008}^{2009} \Delta y_{i t}
$$

Accumulated crisis costs for particular production sectors are calculated separately for each industry according to the formula (3). The authors have made similar calculations for all the European countries. The results are also used in the regression models presented later on.

Table 1. Average crisis costs by industries (\%)

\begin{tabular}{|l|c|c|}
\hline \multicolumn{1}{|c|}{ Production sector according to ISIC codes } & Accumulated two-year cost & Cost in 2008 \\
\hline \multicolumn{1}{|c|}{1} & 2 & 3 \\
\hline Food and beverages & -18.0 & -2.5 \\
\hline Tobacco products & 55.2 & 16.8 \\
\hline Textiles & -54.3 & -18.0 \\
\hline Wearing apparel, fur & -26.6 & -6.7 \\
\hline Leather, leather products and footwear & 11.2 & 8.1 \\
\hline Wood products (excl. furniture) & -52.4 & -16.8 \\
\hline Paper and paper products & -30.8 & -10.4 \\
\hline Printing and publishing & -85.3 & -19.5 \\
\hline Refined petroleum products, nuclear fuel, coke & -16.5 & 3.9 \\
\hline Chemicals and chemical products & -17.6 & -1.2 \\
\hline Rubber and plastics products & -47.4 & -16.0 \\
\hline Non-metallic mineral products & -50.3 & -15.5 \\
\hline Basic metals & -30.0 & 5.8 \\
\hline Fabricated metal products & -48.6 & -7.7 \\
\hline Machinery and equipment & -30.1 & -5.7 \\
\hline Office, accounting and computing machinery & $(*)$ & 41.1 \\
\hline Electrical machinery and apparatus & -22.4 & 3.3 \\
\hline
\end{tabular}




\begin{tabular}{|l|r|r|}
\hline \multicolumn{1}{|c|}{1} & 2 & \multicolumn{1}{|c|}{3} \\
\hline Radio, television and communication equipment & -46.1 & -11.0 \\
\hline Medical, precision and optical instruments & -48.9 & -5.4 \\
\hline Motor vehicles, trailers, semi-trailers & -1.4 & 7.5 \\
\hline Other transport equipment & -20.0 & 8.4 \\
\hline Furniture & -32.3 & -13.9 \\
\hline Recycling & no data & 10.2 \\
\hline Total manufacturing & -37.6 & -8.6 \\
\hline
\end{tabular}

Notes: negative values are tantamount to losses (i.e. crisis costs) whereas positive values indicate that during the crisis production developed more dynamically than before. The field marked with $(*)$ was not filled in due to unbelievably high production value in several countries in 2009 as compared to previous years.

Source: the author's calculations on the basis of INDSTAT2.

The results presented in Table 1 indicate that the industries which suffered most from the global crisis were those less technologically advanced. Printing and publishing, textiles, wood product and non-metallic mineral product sections incurred higher negative deviations from the trend than transport and machinery (of different kinds, including electronic apparatus) or chemical industries. Food, tobacco and leather industries are exceptions here. Table 1 shows that particular industries' costs were the highest only in the second year of the crisis whereas most industries kept a dynamic growth rate in the first year ${ }^{31}$.

\subsection{The factors of the industries' vulnerability to crisis costs}

To research the factors of vulnerability to the global 2008-2009 crisis transmission in the cross-industry perspective (with the information on the crisis costs in the country perspectives used as well), the authors estimate the parameters of the regression models of different specifications (basing on the main model the authors run various regressions each time using the chosen sets of variables).

The base regression model explaining the crisis macroeconomic costs broken down by industries is as follows:

$$
\begin{aligned}
& \text { cost }_{i, j, k}=\alpha+\alpha_{1} \text { sect_openness }_{j, k}+\alpha_{2} \text { intra }_{j, k}+\alpha_{3} \text { unemployment }_{j}+\alpha_{4} \text { investments }_{j}+\alpha_{5} \text { debt }_{j}+ \\
& +\alpha_{6} \text { inflation }_{j}+\alpha_{7} \text { concentration }_{j}+\alpha_{8} \text { openness }_{j}+\alpha_{9} \text { development }_{j}+\alpha_{10} \text { capitalization }_{j}+ \\
& +\alpha_{11} \text { NPL }_{j}+\alpha_{12}\left(\text { caplass }_{j}+\alpha_{13} \text { percentage }_{j}+\alpha_{14} \text { credit }_{j}+\alpha_{15} \text { law }_{j}+\alpha_{16} \text { growth }_{j}+\varepsilon_{i, j, k}\right.
\end{aligned}
$$

where the variable cost denotes the measure of the crisis macroeconomic costs, the index $i=1,2$ represents the method of calculating costs ( 1 means total costs whereas 2 means costs incurred in 2008), the index $j=1,2, \ldots, N$ denotes a country number, and the index $k=1,2$, ..., $M$ is an industry sector index. The variable sect_openness measures the openness of the 
sector $k$ in the economy $j$ before the crisis started, the variable intra measures intra-industry trade with the Gruber-Lloyd method, the variable unemployment measures the unemployment level in a particular economy (as the percentage of the whole labour force), the variable investments denotes the investment level in relation to GDP, the variable debt denotes the level of state government and local government sector debt in relation to GDP, the variable inflation measures the inflation level, the variable concentration measures the concentration level of the economy's sectors, the variable openness measures the economy's openness by means of the relation of aggregate exports and imports to GDP, the variable development represents the economic development level measured as GDP per capita in USD, the variable capitalization denotes the capitalization level of companies listed in a particular country in relation to GDP, the variable $N P L$ measures the share of nonperforming loans in the banking sector, the variable (cap/ass) measures the financial leverage of banks, that is the relation of banks' equity to their assets, the variable percentage denotes the level of market interest rates, the variable credit measures the level of the banking sector development as the relation of bank loans to GDP, the variable law measures the quality of business law according to the World Bank indicator, whereas the variable growth measures the economic growth rate. The random component is marked as $\varepsilon$. All explanatory variables are measured for the year preceding the start of the global financial crisis whereas the crisis costs are measured for the years 2008-2009 ${ }^{32}$.

The model estimation results explaining the accumulated crisis costs in particular industry sectors are presented in Table 2. The first estimated model, shown in the first line of the table, includes all the potential explanatory variables. As some variables appear to be statistically insignificant and additionally some of them are strongly correlated with each other, the authors selected other model specifications by means of appropriate information criteria. Namely, models in which the values of Akaike, Schwarz and Mallows ${ }^{33}$ information criteria are the lowest have been selected as alternative model specifications. Additionally, three methods of averaging models are applied and average estimates of parameters defined after all the combinations of variables used in these models have been taken into account. As the potential influence of an economy's openness on the cost level of the 2008-2009 financial crisis is a particularly significant element in the study, the distribution of parameter estimates for the variable measuring the economy's openness is also tested for all the possible model specifications like in A. Domanska, D. Serwa ${ }^{34}$.

In the first model, which contains all the dependable variables ("full model"), the authors examine how particular economic quantities in individual countries before the 2008-2009 crisis contributed to the crisis' impact in particular industrial sectors in those countries ${ }^{35}$. In this model 
the variables that contributed to the increase in the crisis costs include: industry sector openness and high level of the intra-industry trade measured before the crisis, high real interest rates and high inflation before the crisis, considerable government sector debt before the crisis, high concentration of all industry sectors in the analysed countries, highly developed stock and banking markets, fast economic growth in the pre-crisis period as well as good quality of law. On the other hand, lower crisis costs were incurred by industry sectors in countries that had observed high unemployment, high share of investments in GDP, high share of nonperforming loans and high share of equity in the banking sector's assets (signifying a relatively poorly developed banking system) before the crisis. The economies which were more open and more developed before the crisis incurred, on average, lower crisis costs. The impact directions of particular variables seem to correspond to the intuitive understanding of how the crisis is deepening.

It must be borne in mind that most variables in this model were not statistically significant. For example, the sector openness did not have a statistically significant influence on the crisis costs incurred by this sector whereas considerable openness of the whole economy significantly affected the costs suffered by particular sectors of this economy.

Similar estimation outcomes have been obtained in models selected by means of methods utilizing the estimation of Akaike, Schwarz and Mallows' information criteria. These methods of selecting an appropriate model specification are preferred because they allow to choose models bearing the most information while consisting of a moderate number of explanatory variables ${ }^{36}$. It turns out here that the signs of particular parameters are identical to the ones in the general model and parameter values are similar in most cases. Again, sector openness adverse effect on the crisis costs in cross-sector perspective is not statistically significant. Finally, methods of averaging parameter estimates are applied on the basis of numerous model specifications. Averaging of estimates allows to take into account the risk related to optimal model selection. A single model may not explain an analysed phenomenon appropriately (e.g. precisely), but a combination of multiple models allows to limit the risk of selecting unsuitable model and it raises the resistance of estimates. It turns out that averaged estimates (based on over 60 different model specifications) of particular parameters are very similar to those obtained by estimating the "full" model ${ }^{37}$.

Subsequently, the crisis cost determinants after the first year of the crisis duration are examined, so they are checked for the explanatory variable $\operatorname{costs}_{2, j, k}$. The results are presented in Table 3. All the specifications are shown here in a manner similar to Table 2. Almost all parameter estimates have identical signs to those in the accumulated crisis cost models. The parameter of the variable cap/ass is the only exception as its signs are different depending on specification and it is not statistically significantly different from zero ${ }^{38}$. 


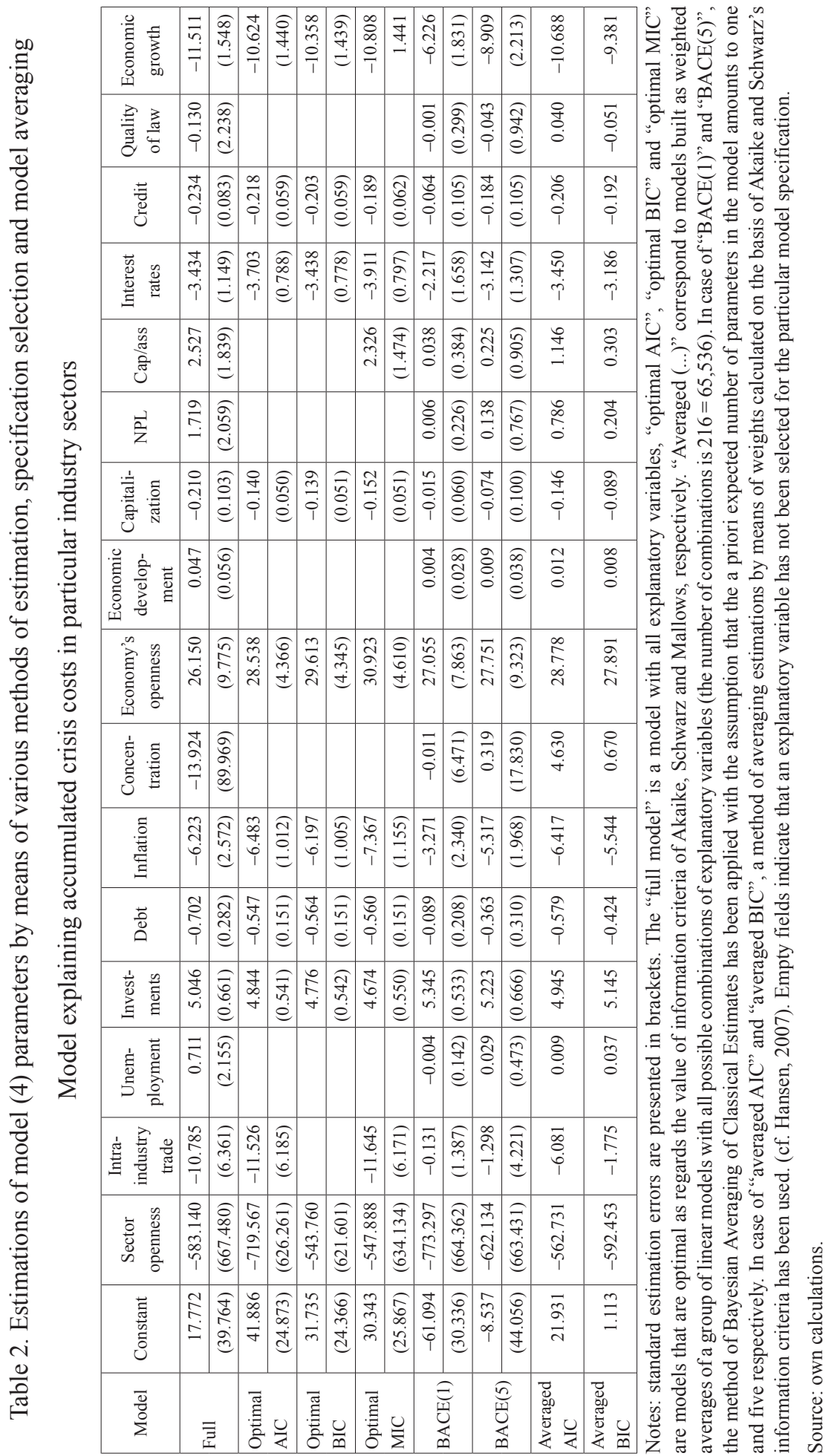




\begin{tabular}{|c|c|c|c|c|c|c|c|c|c|c|c|c|c|c|c|c|}
\hline & 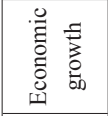 & 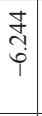 & $\mid \begin{array}{c}6 \\
\stackrel{6}{e} \\
e\end{array}$ & $\begin{array}{l}q \\
0 \\
0 \\
1\end{array}$ & 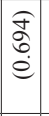 & 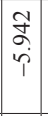 & $\mid \begin{array}{c}\widehat{\vec{a}} \\
\hat{e} \\
\dot{e}\end{array}$ & 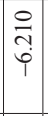 & $\begin{array}{l}\hat{2} \\
\stackrel{i}{e} \\
\end{array}$ & $\begin{array}{l}\infty \\
\stackrel{0}{+} \\
\dot{+}\end{array}$ & $\begin{array}{l}\widehat{\Omega} \\
\\
ٍ\end{array}$ & 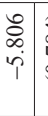 & 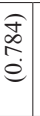 & $\begin{array}{l}\text { dे } \\
\text { †े }\end{array}$ & $\begin{array}{l}\infty \\
\infty \\
\infty \\
p \\
p\end{array}$ & \multirow{5}{*}{ 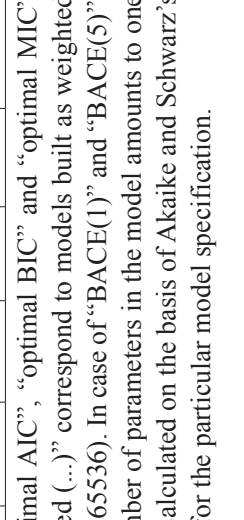 } \\
\hline & 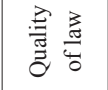 & $\begin{array}{c}\stackrel{0}{\sim} \\
\stackrel{i}{i} \\
i\end{array}$ & $\mid \begin{array}{c}\mathfrak{f} \\
\hat{d} \\
\hat{e}\end{array}$ & $\underset{\substack{f \\
i}}{i}$ & 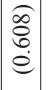 & & & 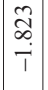 & 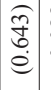 & $\begin{array}{l}\tilde{D} \\
\tilde{o} \\
\dot{i} \\
\end{array}$ & 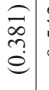 & 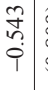 & 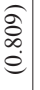 & $\underset{\stackrel{\widetilde{J}}{+}}{\stackrel{\widetilde{T}}{i}}$ & $\begin{array}{l}\overrightarrow{6} \\
\stackrel{0}{0}\end{array}$ & \\
\hline & 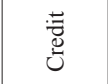 & $\begin{array}{l}\frac{ \pm}{m} \\
\stackrel{0}{0} \\
\end{array}$ & $\begin{array}{c}\hat{\sigma} \\
\tilde{e} \\
\stackrel{\theta}{\dot{\theta}}\end{array}$ & 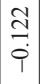 & $\mid \begin{array}{c}\hat{\sigma} \\
0 \\
\dot{\theta} \\
\end{array}$ & $\mid \begin{array}{c}\infty \\
\stackrel{\infty}{0} \\
\stackrel{i}{0}\end{array}$ & $\mid \begin{array}{c}\hat{I} \\
\hat{d} \\
\dot{\theta}\end{array}$ & \begin{tabular}{c}
$\tilde{m}$ \\
\hdashline \\
$\stackrel{9}{0}$
\end{tabular} & 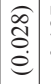 & $\begin{array}{l}\tilde{a} \\
\stackrel{\overrightarrow{9}}{9}\end{array}$ & $\begin{array}{l}\widehat{\vec{c}} \\
\stackrel{\dot{e}}{0}\end{array}$ & $\begin{array}{l}\tilde{m} \\
\stackrel{0}{i}\end{array}$ & 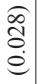 & $\begin{array}{l}\stackrel{0}{0} \\
\stackrel{0}{0}\end{array}$ & 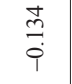 & \\
\hline & 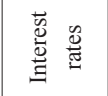 & 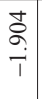 & 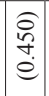 & $\begin{array}{l}\vdots \\
\vdots \\
i \\
i\end{array}$ & 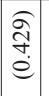 & $\mid \begin{array}{c}0 \\
\mathscr{0} \\
\stackrel{1}{1} \\
1\end{array}$ & \begin{tabular}{|}
$\widehat{\widehat{\Omega}}$ \\
$\hat{e}$ \\
$\hat{e}$
\end{tabular} & 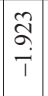 & $\mid \begin{array}{c}\widehat{A} \\
f \\
\stackrel{\tilde{e}}{6}\end{array}$ & $\begin{array}{l}\text { iे } \\
\text { i }\end{array}$ & $\begin{array}{l}\tilde{n} \\
\hat{n} \\
e\end{array}$ & $\begin{array}{c}n \\
\infty \\
i \\
i\end{array}$ & $\begin{array}{l}\widehat{\vec{\sigma}} \\
\dot{c} \\
\dot{e}\end{array}$ & 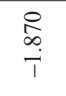 & 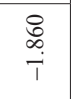 & \\
\hline & 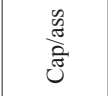 & 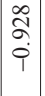 & $\mid \begin{array}{c}\mathbb{E} \\
\stackrel{2}{e} \\
e\end{array}$ & & & & & 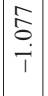 & $\mid \begin{array}{c}\widehat{f} \\
6 \\
\dot{e}\end{array}$ & $\begin{array}{l}\tilde{8} \\
\dot{0} \\
\dot{0}\end{array}$ & $\begin{array}{l}\sigma \\
\infty \\
0 \\
e\end{array}$ & 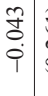 & $\begin{array}{l}\widehat{\widetilde{b}} \\
\stackrel{+}{e}\end{array}$ & 吕 & $\begin{array}{l}\stackrel{+}{0} \\
\stackrel{0}{0}\end{array}$ & \\
\hline $\begin{array}{l}\infty \\
\stackrel{8}{0} \\
\end{array}$ & $\bar{z}$ & $\begin{array}{l}\vec{\vdots} \\
\dot{m}\end{array}$ & $\begin{array}{c}\widehat{\bar{\alpha}} \\
\stackrel{e}{e}\end{array}$ & 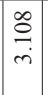 & $\mid \begin{array}{c}0 \\
\infty \\
\infty \\
e \\
e\end{array}$ & $\mid \begin{array}{c}\infty \\
\infty \\
i \\
i\end{array}$ & $\mid \begin{array}{l}0 \\
0 \\
1 \\
e \\
0\end{array}$ & $\begin{array}{l}0 \\
\infty \\
\infty \\
\dot{n}\end{array}$ & $\mid \begin{array}{c}\hat{0} \\
0 \\
\dot{e}\end{array}$ & $\begin{array}{l}\circ \\
\stackrel{1}{\circ} \\
\stackrel{\circ}{-}\end{array}$ & 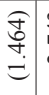 & $\begin{array}{l}\stackrel{m}{t} \\
\stackrel{i}{i}\end{array}$ & 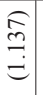 & $\begin{array}{l}\bar{b} \\
\tilde{n} \\
\tilde{n}\end{array}$ & $\begin{array}{c}\substack{\infty \\
\infty \\
i} \\
\text { in }\end{array}$ & 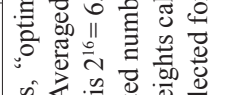 \\
\hline 00 & 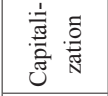 & $\begin{array}{l}\vec{o} \\
\dot{\varphi}\end{array}$ & $\begin{array}{c}\hat{n} \\
\hat{\delta} \\
e \\
\dot{e}\end{array}$ & 姜 & $\begin{array}{l}\stackrel{f}{\tilde{\delta}} \\
\stackrel{\delta}{e} \\
\dot{e}\end{array}$ & & & $\begin{array}{l}\hat{y} \\
0 \\
0 \\
i\end{array}$ & 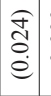 & 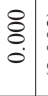 & $\begin{array}{l}\widehat{\tilde{\delta}} \\
\dot{\theta} \\
\end{array}$ & 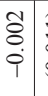 & $\begin{array}{l}\widehat{\Xi} \\
\dot{0} \\
\dot{e}\end{array}$ & $\begin{array}{l}2 \\
\vdots \\
0 \\
i\end{array}$ & 㕝 & रे० \\
\hline 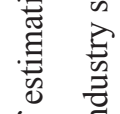 & 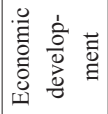 & 号 & 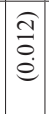 & & & & & & & 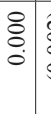 & $\begin{array}{l}\widehat{\hat{\sigma}} \\
\dot{e} \\
\hat{\theta}\end{array}$ & 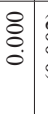 & 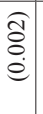 & $\stackrel{0}{0}$ & @ & 氶 \\
\hline 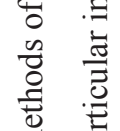 & 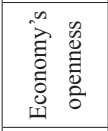 & 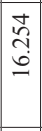 & $\mid \begin{array}{c}\widehat{E} \\
2 \\
\mathfrak{d}\end{array}$ & $\begin{array}{c}8 \\
\stackrel{0}{0} \\
\stackrel{2}{=}\end{array}$ & $\mid \begin{array}{c}\mathscr{d} \\
\stackrel{d}{d} \\
d\end{array}$ & $\begin{array}{l}\overrightarrow{5} \\
\vdots \\
\\
\end{array}$ & $\mid \begin{array}{c}\widehat{\hat{z}} \\
\hat{d} \\
\dot{d}\end{array}$ & $\mid \begin{array}{l}\hat{2} \\
\hat{\hat{\sigma}} \\
-\end{array}$ & $\mid$ & 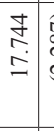 & 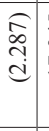 & 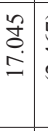 & $\begin{array}{l}\begin{array}{r}6 \\
0 \\
+ \\
\dot{d}\end{array} \\
\end{array}$ & $\begin{array}{l}2 \\
i n \\
0 \\
0\end{array}$ & $\begin{array}{l}\text { fo } \\
\stackrel{0}{6}\end{array}$ & 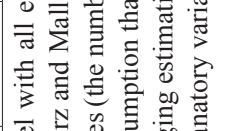 \\
\hline $\begin{array}{l}\tilde{\Xi} \\
. \Xi \\
0\end{array}$ & 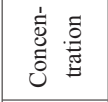 & $\begin{array}{l}2 \\
2 \\
o \\
\dot{0} \\
+\end{array}$ & 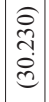 & $\mid \begin{array}{c} \pm \\
\sim \\
\infty \\
\infty \\
i \\
1\end{array}$ & 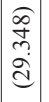 & & & $\stackrel{\hat{\imath}}{\stackrel{n}{n}}$ & $\mid$\begin{tabular}{c|}
$\widehat{\vec{b}}$ \\
$\stackrel{d}{d}$
\end{tabular} & $\begin{array}{ll}\hat{b} \\
\stackrel{0}{0} \\
\dot{1}\end{array}$ & 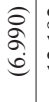 & 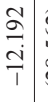 & 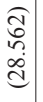 & $\begin{array}{l}\infty \\
\infty \\
0 \\
\text { ते }\end{array}$ & $\begin{array}{l}\stackrel{\infty}{0} \\
\stackrel{0}{0} \\
\end{array}$ & 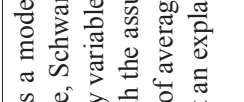 \\
\hline $\begin{array}{l}0 \\
0 \\
0 \\
0\end{array}$ & $\begin{array}{l}\text { 䔍 } \\
\text { 莺 } \\
\end{array}$ & 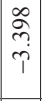 & $\mid \begin{array}{c}\widehat{\hat{\sigma}} \\
\hat{b} \\
\dot{e}\end{array}$ & $\begin{array}{c}\tilde{N} \\
\infty \\
i \\
i\end{array}$ & $\mid \begin{array}{c}\widehat{A} \\
\hat{n} \\
e\end{array}$ & $\mid \begin{array}{l}n \\
\vdots \\
\dot{y} \\
\dot{y}\end{array}$ & $\begin{array}{c}\widehat{a} \\
\tilde{n} \\
e \\
e\end{array}$ & $\mid \begin{array}{l}\infty \\
\infty \\
n \\
p \\
1\end{array}$ & $\mid \begin{array}{c}0 \\
\stackrel{0}{n} \\
e \\
e\end{array}$ & $\begin{array}{l}\stackrel{d}{\mathbb{N}} \\
\stackrel{i}{T}\end{array}$ & $\begin{array}{l}\hat{\infty} \\
\infty \\
e \\
e\end{array}$ & $\begin{array}{l}0 \\
\infty \\
\infty \\
i\end{array}$ & $\begin{array}{l}\hat{f} \\
\text { ? } \\
? \\
e\end{array}$ & $\begin{array}{l}\hat{b} \\
\dot{p}\end{array}$ & $\begin{array}{l}\stackrel{0}{0} \\
\infty \\
i\end{array}$ & 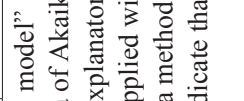 \\
\hline $\begin{array}{l}0 \\
.0 \\
. \Xi\end{array}$ & 苋 & 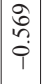 & $\mid \begin{array}{c}\hat{\sigma} \\
\stackrel{9}{e} \\
\dot{e}\end{array}$ & 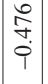 & $\begin{array}{l}\hat{\delta} \\
\vdots \\
\dot{\theta}\end{array}$ & $\frac{0}{0}$ & $\mid \begin{array}{c}\tilde{a} \\
\hat{0} \\
\dot{e}\end{array}$ & $\mid \begin{array}{c}0 \\
\tilde{n} \\
i \\
i\end{array}$ & $\mid$\begin{tabular}{|c}
$\hat{\sigma}$ \\
$\hat{0}$ \\
$\dot{e}$
\end{tabular} & 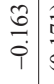 & $\begin{array}{c}\overparen{I} \\
\stackrel{\Xi}{e}\end{array}$ & 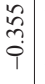 & $\begin{array}{c}\stackrel{\hat{\theta}}{=} \\
\stackrel{\dot{e}}{e}\end{array}$ & 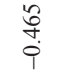 & $\underset{m}{\vec{n}}$ & \\
\hline 菊 & 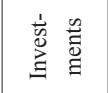 & $\begin{array}{c}0 \\
\stackrel{p}{+} \\
\text { i }\end{array}$ & 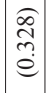 & $\mid \begin{array}{l}\hat{b} \\
\mathfrak{i} \\
i\end{array}$ & \begin{tabular}{|l|}
$\mathscr{o}$ \\
0 \\
$e$ \\
$e$
\end{tabular} & 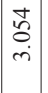 & $\mid \begin{array}{c}\mathfrak{f} \\
\stackrel{f}{s} \\
\stackrel{e}{\varepsilon}\end{array}$ & $\mid \begin{array}{c}n \\
n \\
i \\
i\end{array}$ & 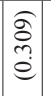 & $\begin{array}{l}\dot{D} \\
\infty \\
\dot{\infty} \\
i\end{array}$ & 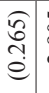 & $\begin{array}{l}\text { ڤे } \\
\text { ì }\end{array}$ & 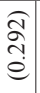 & $\begin{array}{l}\hat{E} \\
\text { i } \\
\text { i }\end{array}$ & $\begin{array}{l}\infty \\
\infty \\
\infty \\
i\end{array}$ & $\begin{array}{l}\dot{0} \\
\dot{0} \\
\dot{v}\end{array}$ \\
\hline$\frac{0}{0}$ & 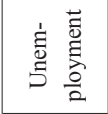 & $\begin{array}{c}\tilde{f} \\
\tilde{f} \\
0\end{array}$ & $\mid \begin{array}{c}\hat{A} \\
\stackrel{e}{e}\end{array}$ & & & & & & & $\begin{array}{l}\vec{\Xi} \\
\dot{\varphi} \\
\dot{0}\end{array}$ & 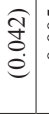 & $\begin{array}{l}\text { 苂 } \\
\dot{0} \\
\dot{q}\end{array}$ & $\begin{array}{l}\tilde{\varepsilon} \\
\stackrel{\varepsilon}{e} \\
\vdots\end{array}$ & $\stackrel{m}{0}$ & $\begin{array}{l}n \\
\stackrel{n}{0} \\
\dot{\varphi}\end{array}$ & $\Xi$ \\
\hline$\frac{8}{8}$ & 焉意兽 & å & $\begin{array}{c}\widehat{\alpha} \\
\stackrel{0}{i d} \\
\dot{d}\end{array}$ & $\frac{m}{\vec{\lambda}}$ & $\begin{array}{c}0 \\
\stackrel{b}{i} \\
i \\
d\end{array}$ & $\begin{array}{l}\tilde{2} \\
\hat{\imath} \\
i\end{array}$ & $\mid \begin{array}{c}\mathfrak{f} \\
\stackrel{\mathfrak{c}}{\mathrm{d}} \\
\mathrm{d}\end{array}$ & $\begin{array}{l} \pm \\
\vec{n} \\
i \\
T\end{array}$ & 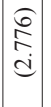 & 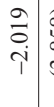 & $\begin{array}{l}0 \\
\infty \\
\infty \\
\infty \\
0\end{array}$ & 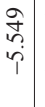 & 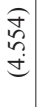 & $\begin{array}{l}\overrightarrow{0} \\
\stackrel{0}{0} \\
\infty\end{array}$ & $\begin{array}{l}\text { ల్లై } \\
\text { } \\
\end{array}$ & Es \\
\hline$\tilde{0}$ & 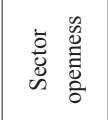 & 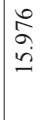 & 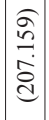 & $\begin{array}{c}\frac{\hat{\vec{n}}}{\sim} \\
\stackrel{\uparrow}{\uparrow}\end{array}$ & 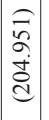 & $\begin{array}{c}\stackrel{a}{a} \\
\infty \\
\dot{\infty} \\
T \\
T\end{array}$ & 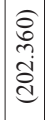 & & 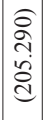 & 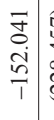 & $\begin{array}{c}E \\
i \\
d \\
d \\
d \\
d\end{array}$ & 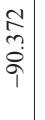 & \begin{tabular}{l} 
d. \\
\multirow{y}{*}{} \\
$\dot{\vec{d}}$
\end{tabular} & $\begin{array}{l}\infty \\
\infty \\
\infty \\
\dot{+} \\
+\end{array}$ & $\begin{array}{l}2 \\
6 \\
10 \\
10\end{array}$ & 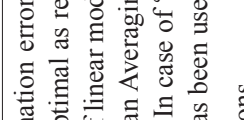 \\
\hline 5 & 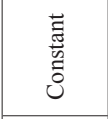 & & $\mid \begin{array}{c}\infty \\
\infty \\
\stackrel{0}{1} \\
\stackrel{\Xi}{=}\end{array}$ & $\mid \begin{array}{l}8 \\
\vdots \\
\vdots \\
i \\
m\end{array}$ & 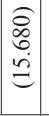 & $\mid \begin{array}{l}\vec{b} \\
\dot{6} \\
1\end{array}$ & $\left|\begin{array}{c}0 \\
\infty \\
\infty \\
0 \\
0\end{array}\right|$ & $\mid \begin{array}{l}\infty \\
2 \\
\hat{q} \\
\tilde{\gamma}\end{array}$ & 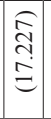 & 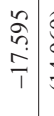 & $\begin{array}{l}\hat{\sigma} \\
\stackrel{\alpha}{+} \\
\dot{+}\end{array}$ & $\begin{array}{l}\stackrel{\infty}{\infty} \\
\stackrel{+}{-}\end{array}$ & 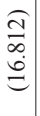 & $\begin{array}{l}\text { ते } \\
\text { ర్సं }\end{array}$ & $\begin{array}{l}8 \\
i n \\
+\end{array}$ & $\frac{\pi}{\mathbb{E}}$ \\
\hline & $\begin{array}{l}\overline{\vec{\pi}} \\
\stackrel{0}{\Sigma}\end{array}$ & & & & & 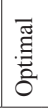 & $\stackrel{\circlearrowright}{\infty}$ & & $\stackrel{U}{\Sigma}$ & 莺 & 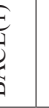 & & & 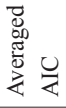 & 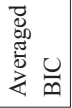 & 记 \\
\hline
\end{tabular}


What is important is the result indicating that the parameter for the variables "the whole economy's openness" is positive regardless of a model specification whereas the parameter for the variable "sector openness" has a negative value. It was confirmed by other outcomes presented in Table 3, where all parameter values for the variable "the whole economy's openness" and "sector openness" were tested for all model combinations (also the ones of poorer quality $)^{39}$. Table 3 presents the parameter values for different specifications of the crisis cost model. It appears that in most cases the whole economy's openness before the crisis contributed to lowering the crisis costs (an output gap between the real GDP and the theoretical one is positive). On the other hand, the sectors' openness usually had a negative sign (increasing the crisis costs in industries).

Unequivocal conclusions on positive or negative impact of this variable on the 2008 crisis costs are, therefore, unjustified.

To sum up, the whole economy's significant openness contributed to lowering the financial crisis costs in particular industry sectors in the European countries. On the other hand, individual branches' openness had a reverse effect on the costs incurred by those branches during the crisis (the crisis costs were higher in more open branches). The latter result appears to be explicit for the two-year period of crisis, but it was not observed in $2008^{40}$. The results presented in both tables referring to both types of the crisis costs showed also the positive parameters of the variables indicating intra-industry trade and the level of production's concentration. Those results confirm the stylised facts accepted by the majority of researchers about the role of the concentration and the intra-industry international trade in creating favourable conditions for transmitting the economic impulses among the countries (i.e. in making them more vulnerable to foreign economic shocks).

\section{Conclusions}

The study presented in hereby article is aimed at analysing the selected (considered as significant by theoretical concepts and postulates of the world literature) factors of the European economies' vulnerability to effects of foreign macroeconomic shocks on the example of the 2008-2009 world crisis. Since it was the collapse of the international trade which substantially contributed to the general fall in GDP in the European countries', the authors have assumed that the fall in production seen from the cross-industry perspective tied to demand decrease in the partner countries (resulting in international trade slump) significantly deepened the crisis in Europe (by the multiplier effect). That is why the authors focused on the search for the factors 
connected with the characteristics of individual industries, mainly those related to international trade - as the level of production and export basket concentration versus specialization, the "type" of trade (inter- versus intra-industry) etc.

The paper consists of two parts: a theoretical and an empirical one. The first part comprises a literature review and presents the most important postulates concerning the title issues proposed by other authors. Basing on a review of theoretical concepts, the authors selected indicators and data (as factors) that were taken into account in the empirical analysis presented in the second part of the paper, where they estimated several specifications of the model provided in the research method description. The factors of the present study include in particular: economy and export branch structure, the level of specialization versus diversification of export basket and production broken down by the analysed European countries, trade openness at the level of countries and branches, intra-industry or inter-industry trade in particular industries as well as financial openness. The authors also tried to determine which industries in the European countries appeared to be the least resistant to 2008-2009 global crisis, i.e. which of them incurred the highest crisis costs, which means that they transmitted the crisis on a larger scale.

The regression model was developed to examine which individual sectors' and which the whole economies' features generated higher crisis costs. The study shows that the general openness of the whole country's economy did not contribute to the increase of the crisis costs. On the other hand, the openness of individual branches, high level of intra-industry trade as well as more concentrated structure of the economies' production and export strengthened the effect of the 2008-2009 crisis in the cross-industry perspective. On average, the costs incurred by the branches were substantially higher in the second year of the crisis.

The above mentioned results seem to be particularly significant from the economic authorities' perspective as they have an interest in the increase of particular sectors' resistance to adverse effects of external shocks.

\section{Notes}

1 The 2008-2009 crisis (or as some sources refer to it: "2007-2009 crisis"), which started with mortgage market downturn in the USA, was initially a financial crisis and spread mainly through international linkages of capital markets (herd behaviour among investors, adverse effects of capital concentration, etc.). However, the financial crisis quickly transferred to the real economy, having a negative impact on the world output and economic development.

2 This question refers not only to the foreign economic impacts during the crisis, but also later on - during the recovery, as well as in a stable "normal" economic situation.

3 Domanska (2011a); Domanska (2012).

4 Lubiński (2006). 
${ }^{5}$ For example Domanska (2010); Domanska, Serwa (2013a); Domanska, Serwa (2013b).

${ }^{6}$ A literature review on this subject is included, e.g., in Forbes (2002).

7 Glick, Rose (1999).

${ }^{8}$ Domanska (2012) and her other studies.

${ }^{9}$ Forbes (2001).

${ }^{10}$ See Domanska (2012); Domanska, Serwa (2013).

11 Eichengreen, O’Rourke (2009).

${ }^{12}$ Levchenko, Lewis, Tesar (2010); Chinn (2009); Freud (2009); Cheung, Guichard (2009); Amador, Cabral (2009); Mirodout, A. Ragoussis (2009); Alessandria, Kaboski, Midrigan (2010); Amiti, Weinstein (2009); Haddad, Harrison, Hausmann (2010). See more in Domańska (2012).

${ }^{13}$ Domańska (2011a).

${ }^{14}$ Financial openness will be omitted as it does not belong to the main issue of the discussion in this article.

15 More on this topic in Domańska (2010).

${ }^{16}$ Domańska (2010); Domańska (2011b).

${ }^{17}$ Wacziarg (2001); Irwin, Terviö (2002); Kose, Prasad, Terrones (2005); Arora, Vamvakidis (2005); Edwards (1998).

18 Alesina, Spolaore, Wacziarg (2005); Calderon, Loayza Schmidt-Hebbel (2005).

19 Rodrik (1997); di Giovanni, Levchenko (2008); Jansen, Lennon, Piermartini (2009).

${ }^{20}$ e.g., Martin, Mitra (2001); Irwin (2000); Wright, Czelusta (2007); Lederman, Maloney (2007).

${ }^{21}$ Detailed literature review on this topic in Domańska (2011b) and Domańska (2012).

22 Michaely (1958).

23 Domańska (2011b); Domańska (2012)

${ }^{24}$ Calderon, Loayza, Schmidt-Hebbel (2005); Cabellero, Cowan (2006); Hausmann,, Hwang, Rodrik (2003); Hausmann, Rodrik (2003); Hausmann, Klinger (2006); Klinger, Lederman (2006); Easterly, Loayza, Montiel (1997); FernándezArias, Montiel (2001); Al-Marhubi (2000); Agosin (2007); Gutierrez de Pineres, Ferrantino (1997); Herzer, NowakLehmann (2006); Lederman, Maloney (2009); Koren, Tenreyro (2007); di Giovanni, Levchenko (2008).

25 Krugman (1993).

${ }^{26}$ More on this topic in Domanska (2011b); Domanska (2012).

${ }^{27}$ e.g., Clark, van Wincoop (2001); Imbs (2003); Bejan (2006).

${ }^{28}$ More on this topic in Domanska (2011b); Domanska (2012); A. Domanska, D. Serwa (2013b).

${ }^{29}$ Dell'Ariccia, Detragiache i Rajan (2005); Hoggarth, Reis, Saporta (2002); Hutchinson, Noy (2005).

30 See more in Domanska, Serwa (2013c) and other papers by the authors.

31 See A. Domanska, D. Serwa (2013b).

32 Similarly like in Domanska, Serwa (2013a).

33 Akaike (1974).

${ }^{34}$ Domanska, Serwa (2013b)

35 Similarly like in Domanska, Serwa (2013a).

${ }^{36}$ Similarly like in Domanska, Serwa (2013a); Domanska, Serwa (2013b).

${ }^{37}$ Domanska, Serwa (2013b).

38 Similarly like in Domanska, Serwa (2013a).

${ }^{39}$ Domanska, Serwa (2013b). 


\section{References}

Agosin, M.R. (2007). Export Diversification and Growth in Emerging Economies. Working Paper 233. Departamento de Economía, Universidad de Chile, Santiago.

Akaike, H. 1974, A New Look at the Statistical Model Identification, I.E.E.E. Transactions on Automatic Control, 19, 716-723.

Alesina, A., Spolaore, E. \& Wacziarg R. (2005). Trade, Growth, and Size of Countries. In: P. Aghion, S. Durlauf (Eds.), Handbook of Economic Growth, Amsterdam.

Alessandria, G., Kaboski, J.P. \& Midrigan, V. (2010) The Great Trade Collapse of 2008-2009: An Inventory Adjustment? NBER Working Paper 16059, June.

Al-Marhubi, F. (2000). Export Diversification and Growth: An Empirical Investigation. Applied Economics Letters, 7, 559-562.

Amador, J. \& Cabral, S. (2009). Vertical Specialization Across the World: A Relative Measure. North American Journal of Economics and Finance.

Amiti, M. \& Weinstein, D.E. (2009). Exports and financial shocks, Preliminary draft, NBER September.

Arora, V. \& Vamvakidis V.A. (2005). How much do Trading Partners matter for Economic Growth? IMF Staff Papers, 52, 24-40.

Bejan M., (2006), Trade Openness and Output Volatility, MPRA Paper 2759, University Library of Munich.

Ben-David, D. (1993). Equalizing Exchange: Trade Liberalization and Income Convergence. Quarterly Journal of Economics, 108 (3), 653-679.

Burstein, A., Kurz, Ch. \& Tesar L. (2008). Trade, Production Sharing, and the International Transmission of Business Cycles. Journal of Monetary Economics, 55, 775-795.

Cabellero, R.J. \& Cowan, K. (2006). Financial Integration without the Volatility. Massachusetts Institute of Technology, Cambridge, MA.

Calderon, C., Loayza, N. \& Schmidt-Hebbel, K. (2005). Does Openness Imply Greater Exposure? The World Bank.

Cheung, C. \& Guichard, S. (2009). Understanding the World Trade Collapse, Economic Department Working papers no. 729, OECD 2009.

Chinn, M. (2009). What Does the Collapse of US Imports and Exports Signify? June 23.

Claessens, S., Dornbush, R. \& Park, G. (2001). Why Contagion, crises spread and how this can be stopped.In: S. Claessens \& K.J. Forbes (Eds.) International financial contagion. Boston: Kluwer Academic Publishers.

Clark, T.E. \& Wincoop, E. van, (2001). Borders and business cycles. Journal of International Economics, Elsevier, Vol. 55 (1), pp. 59-85. 
Corsetti, G, Pericoli, M. \& Sbracia, M. (2000). A perspective on empirical studies of contagion and interdependence. World Bank.

De Santis, R. (2000). Trade as international transmission mechanism of shocks: The case of Central Eastern European Countries. Universita degli Studi di Roma.

Dell'Ariccia, G., Rajan, R. \& Detragiache, E., (2005), The Real Effect of Banking Crises, IMF Working Papers 05/63, International Monetary Fund.

di Giovanni, J., Levchenko, A.A. (2008). Trade Openness and Volatility. IMF Working Paper 2008, WP/08/146.

Domańska, A. (2010). Otwartość gospodarki jako uwarunkowanie poziomu $i$ wahań wzrostu gospodarczego. Kontrowersje wokót teorii $i$ wyników badań empirycznych. Collegium of Socio-Economics own research. Warsaw: Warsaw School of Economics.

Domańska, A. (2011a). Rozprzestrzenianie się kryzysów gospodarczych: mechanizmy $i$ uwarunkowania - przegląd koncepcji teoretycznych. Prace i Materiały ISM 2011 nr 40, Instytut Studiów Międzynarodowych, SGH, Warszawa, pp. 9-25.

Domańska, A. (2011b), Uwarunkowania podatności gospodarek na szoki w globalnej wymianie handlowej, The study was done within statutory research of Institute for International Studies in Collegium of Socio-Economics, Warsaw School of Economics, pp. 18-20.

Domańska, A. (2012), Struktura i cechy handlu zagranicznego w kształtowaniu wrażliwości wzrostu gospodarczego na wpływ otoczenia ekonomicznego a transmisja kryzysu 2007 2009. Ekonomia (Economics) nr 1 (18) 2012, Economic University Wrocław, pp. 44-60.

Domańska, A. \& Serwa, D. (2013a). Czynniki wrażliwości gospodarek na szoki zewnętrzne na przykładzie skutków kryzysu 2008-2009 - analiza empiryczna. Polityki Europejskie, Finanse i Marketing, nr 9/58/2013, ZN SGGW w Warszawie, pp. 110-124.

Domańska, A. \& Serwa, D. (2013b). Wrażliwość branż produkcyjnych w Europie na skutki kryzysu a struktura handlu zagranicznego. Analiza w perspektywie grup krajów - paper presented on the Conference "Tradycyjne i nowe kierunki handlu zagranicznego". Uniwersytet Ekonomiczny w Krakowie.

Domańska, A. \& Serwa, D. (2013c). Factors of the European economies' vulnerability to external shocks: An empirical analysis on the example of 2008-2009 crisis costs. International Journal of Management and Economics, Kolegium Gospodarki Światowej SGH, ZN 40/2013.

Easterly, W. \& Rebelo, S. (1993). Fiscal Policy and Economic Growth: An Empirical Investigation, NBER Working Paper No. 4499.

Easterly, W. \& Levine, R. (2002). Tropics, Germs, and Crops: How Endowments Influence Economic Development, NBER Working Paper 9106.

Easterly, W. Loayza, N. \& Montiel, P. (1997). Has Latin America's Post-Reform Growth Been Disappointing? Journal of International Economics, 43, pp. 287-311. 
Economics 24, pp. 239-248.

Edwards, S. (1998) Openness, productivity and growth: What do we really know? The Economic Journal, Vol. 108, pp. 383-399.

Eichengreen, B. \& O’Rourke, K.H. (2009). A Tale of Two Depressions, VoxEU.org.

Eichengreen, B. \& Rose, A.K. (1999). Contagious currency crises: Channels of conveyance. In: T. Ito, A.O. Krueger (Eds.), Changes in exchange rates in rapidly developing countries: Theory, Practice and policy issues, Chicago: University of Chicago Press.

Fernández-Arias, E. \& Montiel, P. (2001). Reform and Growth: All Pain, No Gain? IMF Staff Papers 48 2001, pp. 522-546.

Forbes, KJ. (2001). Are Trade Linkages Important Determinants of Country Vulnerability to Crises? NBER Working Paper No. 8194, March.

Freud, C. (2009). The trade response to Global Downturns: Historical Evidence. World Bank Policy Research Working Paper 5015.

Gerlach, S. \& Smets, F. (1995). Contagions Speculative Attacks, European Journal of Political Economy, No. 1.

Glick, R. \& Rose, A.K. (1999). Contagion and trade: Why are currency crises regional? Journal of International Money and Finance, 18, pp. 603-617.

Gutierrez de Pineres, A.S. \& Ferrantino, M.J. (1997). Export Diversification and Structural Change: Some Comparisons for Latin America, http://ssrn.com/abstract=36231.

Haddad, M., Harrison, A. \& Hausmann, C. (2010). Decomposing the great trade collapse: products, prices, and quantities in the 2008-2009 crises, NBER Working Paper 16253, August.

Hansen, C.B. (2007). Generalized Least Squares Inference In Panel and Multilevel Models with serial correlation and fixed effects. Journal of Econometrics, 140, pp. 670-694.

Hausmann, R. \& Klinger, B. (2006). Structural Transformation and Patterns of Comparative Advantage in the Product Space. Working Paper 128. Center for International Development, Harvard University, Cambridge, MA.

Hausmann, R., Hwang J. \& Rodrik, D., What You Export Matters. Center for International Development Working paper, Harvard University, Cambridge, MA.

Hausmann, R. \& Rodrik, D. (2003). Economic Development as Self-Discovery. Journal of Development Economics 72: 2003, 603-33.

Herzer, D., \& Nowak-Lehmann, D.F. (2006). What Does Export Diversification Do for Growth? An Econometric Analysis. Applied Economics 38: 1825-1838.

Hoggarth, G., Reis, R., Saporta, V. (2002). Costs of banking system instability: Some empirical evidence. Journal of Banking \& Finance, Elsevier, Vol. 26 (5), pp. 825-855. 
Hutchison, M. \& Noy, I. (2005). How Bad Are Twins? Output Costs of Currency and Banking Crises. Journal of Money, Credit and Banking, Blackwell Publishing, Vol. 37 (4), pp. 725-752.

Imbs, J. (2003). Trade, Finance, Specialization, and Synchronization, IMF Working Papers 03/81, International Monetary Fund.

Irwin, D. (2000). How Did the United States Become a Net Exporter of Manufactured Goods? NBER Working Paper 7638, National Bureau of Economic Research, Cambridge, MA.

Irwin, D.A., Terviö M. (2002). Does Trade raise Income? Evidence from the Twentieth Century. Journal of International Economics, 58, pp. 1-18.

Jansen, M., Lennon, C. \& Piermartini, R. (2009). Exposure to External Country Specific Shocks and Income Volatility. World Trade Organization Staff Working Paper, January.

Klinger, B. \& Lederman, D. (2006). Diversification, Innovation, and Imitation inside the Global Technological Frontier. Research Policy Working Paper 3872. Washington DC: World Bank.

Koren, M. \& Tenreyro, S. (2007). Volatility and Development. Quarterly Journal of Economics, Vol. 122, No. 1 (February), pp. 243-287.

Kose, M.A., Prasad, E.S. \& Terrones, M. (2005). How do Trade and Financial Integration affect the Relationship between Growth and Volatility? IMF Working Paper WP/05/19, January.

Krugman, P. (1993). Lessons of Massachusetts for EMU. In: F. Torres, F. Giavazzi, (Ed.) Adjustment and Growth in the European Monetary Union. Cambridge, MA: Cambridge University Press, pp. 241-260.

Lederman, D. \& Maloney, W.F. (2009). Trade Structure and Growth. In: R. Newfarmer, W. Shaw, P. Walkenhorst, Breaking into New Markets: Emerging Lessons for Export Diversification. Washington DC: World Bank.

Lederman, D. \& Maloney, W.F. (2007). Trade Structure and Growth. In: D. Lederman \& W.F. Maloney (Eds.), Natural Resources: Neither Curse nor Destiny. 15-39. Washington DC: World Bank and Stanford University Press.

Levchenko, A., Lewis, L. \& Tesar, L. (2009). The Collapse of International Trade During the 2008-2009 Crisis: in Search of the Smoking Gun, RSIE Discussion Paper 592, October.

Levchenko, A.A., Lewis, L.T. \& Tesar, L.L. (2010). The collapse of international trade during the 2008-2009 crisis: in search of the smoking gun. NBER Working paper 16006, May 2010.

Lubiński, M. (2006). Analiza koniunktury i badanie rynków. Warszawa: Elipsa,

Martin, W. \& Mitra, D. (2001). Productivity growth and Convergence in Agriculture and Manufacturing. Economic Development and Cultural Change, 49 (2).

Michaely, M. (1958). Concentration of Exports and Imports. The Economic Journal, 68 (272). 
Mirodout, S. \& Ragoussis, A. (2009). Vertical Trade,Trade Costs and FDI, OECD Trade Policy Working Paper

Newbery, D.M. \& Stiglitz, J.E. (1984). Pareto Inferior Trade. Review of Economic Studies, Vol. 51, No. 1, pp. 1-12.

Prebish, R (1959). Commercial Policy in the Underdeveloped Countries. American Economic Review, Papers and Proceedings, 49 (2).

Rodrik, D. \& Rodríguez, F. (2000). Trade Policy and Economic Growth: A Skeptics Guide to the Cross-National Evidence, NBER Macroeconomics Annual 15. Cambridge, MA: MIT Press.

Rodrik, D. (1997). Has Globalization Gone Too Far? Washington DC: Institute for International Economics.

Sachs, J.D. \& Warner, A.M. (1995). Economic Convergence and Economic Policies. NBER Working Paper.

Wacziarg, R. (2001). Measuring the Dynamic Gains from Trade. World Bank Economic Review, $15(3)$.

Wright, G. \& Czelusta, J. (2007). Resource-Based Growth Past and Present. In: D. Lederman, W. Maloney (Eds.), Natural Resources: Neither Curse nor Destiny. Washington DC: World Bank and Stanford University Press, pp. 183-211. 